\title{
Toxicity and sublethal effects of chlorantraniliprole and indoxacarb on Spodoptera littoralis (Lepidoptera: Noctuidae)
}

\author{
Moataz A. M. Moustafa ${ }^{1} \cdot$ Eman A. Fouad ${ }^{2} \cdot$ Yasmin Abdel-Mobdy $^{1} \cdot$ Kamirán Áron Hamow $^{3} \cdot$ Zsanett Mikó $^{4}$. \\ Béla Péter Molnár ${ }^{3}$. Adrien Fónagy ${ }^{3}$
}

Received: 22 April 2020 / Accepted: 17 December 2020 / Published online: 8 January 2021

(C) The Japanese Society of Applied Entomology and Zoology 2021

\begin{abstract}
Chlorantraniliprole and indoxacarb insecticides exhibit good efficiency for control lepidopteran pests. The current study is a comprehensive analysis of the effect of lethal and sublethal concentrations of these insecticides on Spodoptera littoralis (Boisduval) (Lepidoptera: Noctuidae) by using the leaf dipping technique. The $\mathrm{LC}_{50}$ values ranged from 0.06 to $1.07 \mathrm{mg} / \mathrm{L}$, and 0.005 to $0.81 \mathrm{mg} / \mathrm{L}$ for chlorantraniliprole and indoxacarb, respectively. Our results showed that the treatment of the $2 \mathrm{nd}$ instar larvae with $\mathrm{LC}_{50}$ concentrations of these insecticides significantly increased the length of larval and pupal duration as well as pupal weight in most cases. While, no significant differences have been found in the percentage of hatchability except for $\mathrm{LC}_{50}$ equivalent of indoxacarb. Female behavior regarding calling activity decreased by $50-60 \%$ following exposure to the $\mathrm{LC}_{50}$ concentration of both insecticides. Gas chromatography analysis results showed that both insecticides lowered pheromone titer except at chlorantraniliprole $\mathrm{LC}_{50}$ equivalent for $(Z, E)$-9,12-tetradecadien-1-ol acetate, and indoxacarb $\mathrm{LC}_{10}$ equivalent for (Z)-9-tetradecenyl acetate. Additionally, the activity of mixed-function oxidases and glutathione S-transferase were elevated relative to control. The carboxylesterase activity significantly increased when assayed with both chlorantraniliprole concentrations and indoxacarb $\mathrm{LC}_{10}$ equivalent. These results indicate that chlorantraniliprole and indoxacarb could be effective for $S$. littoralis control.
\end{abstract}

Keywords Toxicity $\cdot$ Sublethal concentration $\cdot$ Chlorantraniliprole $\cdot$ Indoxacarb $\cdot$ Spodoptera littoralis

Supplementary Information The online version of this article (https://doi.org/10.1007/s13355-020-00721-7) contains supplementary material, which is available to authorized users.

Moataz A. M. Moustafa

moataz.moustafa79@gmail.com

1 Department of Economic Entomology and Pesticides, Faculty of Agriculture, Cairo University, Giza 12613, Egypt

2 Bioassay Department, Central Agricultural Pesticides Laboratory, Agriculture Research Center, Giza 12618, Egypt

3 Zoology Department, Plant Protection Institute, Centre for Agricultural Research, Hungarian Academy of Sciences, 1022 Budapest, Hungary

4 Lendület Evolutionary Group, Plant Protection Institute, Centre for Agricultural Research, Hungarian Academy of Sciences, 1022 Budapest, Hungary

\section{Introduction}

Cotton leafworm, Spodoptera littoralis (Boisduval) (Lepidoptera: Noctuidae), is a destructive polyphagous insect pest of diverse field crops in different regions including; tropical and subtropical (Carter 1984). S. littoralis feeds on approximately 90 species of economic crops in 40 plant families (El-Sheikh et al. 2018). The regular use of chemical insecticides against $S$. littoralis resulted in the development of resistances to most of the traditional insecticides (Aydin and Gürkan 2006; Ishaaya et al. 1995) and some of the newer bioinsecticides such as spinosad and abamectin (Gamal et al. 2009). Therefore, there is an increasing need for alternative new classes of insecticides that may delay or prevent resistance development.

Diamide insecticides, such as chlorantraniliprole, for pest control, are one of the most promising new class of insecticides that have excellent efficacy and low hazard for mammals (Lahm et al. 2009). Chlorantraniliprole (Bentley et al. 2010), has an insecticidal effect on a wide range of 
lepidopteran pests (Hannig et al. 2009; Lahm et al. 2005) besides other orders including Coleoptera, and Diptera (Lanka et al. 2013; Sattelle et al. 2008). Chlorantraniliprole is classified by the insecticide resistance action committee as class 28 (IRAC 2019), which modulates functionality of the ryanodine receptor, that regulate the intracellular $\mathrm{Ca}^{2+}$ channels specialized for the release of $\mathrm{Ca}^{2+}$ into the muscles. Consequently, it has the potential to be one of the most successful agents in resistance management due to its mode of action (Guo et al. 2013).

Indoxacarb is another non-traditional insecticide that belongs to the oxadiazine insecticide group that is used against different species of insect pests in agricultural and urban environments (Gondhalekar et al. 2011; Harder et al. 1996; Wing et al. 2000). Indoxacarb is in class 22A (IRAC 2019) that effects by blocking the voltage-dependent $\mathrm{Na}^{+}$ channel and leading to paralysis of the insect. It is enzymatically bioactivated by insect esterases or amidases to a decarbomethoxylated metabolite, which is more effective than the parent compound, Indoxacarb (Wing et al. 1998; Zhao et al. 2005).

Successful pest control depends on the prolongation of the efficacy of insecticides. Therefore the assessment of the sublethal effects of an insecticide is important, and several studies on the sublethal effects of insecticides have been reported for a number of lepidopteran pests including Plutella xylostella (Linnaeus) (Lepidoptera: Plutellidae) (Guo et al. 2013; Wang et al. 2011; Yin et al. 2008), Helicoverpa armigera (Hübner), S. littoralis and Mamestra brassicae (Linnaeus) (Lepidoptera: Noctuidae) (El-Sheikh 2015; Moustafa et al. 2016; Parsaeyan et al. 2013; Shen et al. 2013). The disturbance could reflect protective physiological responses such as the increment of cytochrome P450-dependent monooxygenases, carboxylesterases (CarE), and/or glutathione S-transferases (GST) that play important roles in insecticide metabolism (Yu 2004). The P450s and CarE catalyze phase I reactions by participating in the direct metabolism of insecticides, while the GSTs catalyze phase II reactions by increasing the molecule's hydrophilicity of compounds to be excreted by $\mathrm{ABC}$ transporters during phase III (Crava et al. 2016; Zhong et al. 2017). The insecticide resistance could be developed as a result of the induction of detoxification enzymes following insecticides exposure (He et al. 2019).

Locating conspecific females for mating is a critical event in the life of adult moths. Most moth species produce in the female pheromone gland (PG) (Percy and Weatherston 1974) species-specific sex pheromones, composed of longrange aliphatic compounds (Ando et al. 2004). Release of sex pheromone blends correlates in time with high male responsiveness and locomotor activity (Raina et al. 1987). The circadian mating activity has been extensively studied by Silvegren et al. (2005) in S. littoralis. In S. littoralis, the highest pheromone titers are found in the PGs of 1-3 day (D) old females during the 2nd and 3rd hours of scotophase (Dunkelblum et al. 1987) with several $\mathrm{C}_{14}$ acetates identified in the PG extracts of S. littoralis (Nesbitt et al. 1973; Tamaki and Yushima 1974; The Pherobase). The Egyptian strain is characterized to include the major components $(Z, E)$-9,11-tetradecadienyl acetate $[(Z, E)$ 9,11-14:Ac] and $(Z, E)-9,12$-tetradecadienyl acetate $[(Z, E) 9,12-14$ :Ac] with 3 minor components: $(Z)-9$-tetradecenyl acetate (Z9-14:Ac), (E)-11-tetradecenyl acetate (E11-14:Ac) and (Z)-11-tetradecenyl acetate (Z11-14:Ac) (Campion et al. 1980; The Pherobase).

Sublethal doses/concentrations could result in the disorder of behavioral and physiological parameters of insects that survive after the initial insecticide exposure (Desneux et al. 2007). The current work provides information about the susceptibility of $S$. littoralis to chlorantraniliprole and indoxacarb and assesses their sublethal effects on insect development, various reproductive activity parameters (calling behavior, pheromone titer, fecundity and hatchability percentage) and critical detoxification enzyme activities such as mixed-function oxidases (MFOs), CarE and GST.

\section{Materials and methods}

\section{Spodoptera littoralis culture}

Spodoptera littoralis have been collected from the field at Giza governorate, Egypt. The colony is reared in the laboratory for more than 20 generations in the absence of insecticides as described by El-Defrawi et al. (1964). All stages of S. littoralis were maintained in a rearing room at $25 \pm 1{ }^{\circ} \mathrm{C}$, $75 \pm 5 \%$ relative humidity under a reversed $16 \mathrm{~h}: 8 \mathrm{~h}$ (light: dark) regime, with lights-off at 8:00 a.m. and on at 4:00 p.m. Larvae were fed with fresh castor bean leaves (Ricinus communis; Malpighiales: Euphorbiaceae). Male and female pupae were separated to avoid mating. Emerged moths were supplied with a $10 \%$ sugar solution. For a limited number of experiments, assays were conducted separately in another room equipped with a dim bright red backlight, but under the same rearing conditions.

\section{Insecticides and chemicals}

Chlorantraniliprole (Coragen® 20\%, suspension concentrate, DuPont, France), and Indoxacarb (Avaunt ${ }^{\circledR} 15 \%$, emulsifiable concentration, DuPont) were used for the experiments. The pheromone standards, a blend comprising synthetic mixtures of neat compounds, were from Pherobank BV (The Netherlands). Fast blue salt, glutathione (GSH), p-nitroanisole (p-NA), 1-chloro-2,4-dinitrobenzene (CDNB) were obtained from Sigma-Aldrich (Germany) and $n$-hexane 
from Merck (Germany). Other substrates and reagent chemicals were purchased from Sorachim (Switzerland), and MP Biomedicals companies (India).

\section{Bioassays}

The toxicity of chlorantraniliprole and indoxacarb were tested using the leaf dipping technique on S. littoralis larvae comprising all 6 instars. The castor bean leaves were dipped for $20 \mathrm{~s}$ in five different concentrations ranging from 0.0078 to $4 \mathrm{mg} / \mathrm{L}$ of chlorantraniliprole and from 0.0019 to $4 \mathrm{mg} / \mathrm{L}$ of indoxacarb for each instar as indicated in the supplementary material. The treated leaves were allowed to dry, after which a pair of leaves were placed into a glass jar $(0.5 \mathrm{~L})$ with 25 larvae in 4 replicates. Control larvae were placed on untreated leaves. The larvae were allowed to feed for $24 \mathrm{~h}$ and then transferred onto untreated leaves. Mortality was recorded at 24 and $96 \mathrm{~h}$ to estimate the lethal and sublethal concentrations after 4 days post-treatment of each insecticide. The bioassay was repeated twice.

\section{Sublethal effects of chlorantraniliprole and indoxacarb on S. littoralis: effects on insect development}

Sublethal concentration values corresponding to the $\mathrm{LC}_{10}$ $(0.01$ and $0.001 \mathrm{mg} / \mathrm{L})$ and $\mathrm{LC}_{50}(0.09$ and $0.01 \mathrm{mg} / \mathrm{L})$ of both chlorantraniliprole and indoxacarb were used to assess effects on the larval and pupal duration, pupation percentage, and emergence percentage. The larval duration was recorded daily until the last instar and then transferred individually to a clean cup for pupation. After 3 days, pupae were sexed, weighed, and kept separately to record the total pupal duration period, and emergence percentage. The following formula has been used: and kept for D5 to record the hatchability percentage as follows:

Hatchability percentage $=\mathrm{n}$. of hatching eggs/Total number of eggs.

\section{Monitoring virgin female calling behavior}

Calling behavior was recorded from D1 until D5 in surviving virgin female moths after sublethal $\left(\mathrm{LC}_{10}\right.$ and $\mathrm{LC}_{50}$ values) insecticide exposure in second larval instar and controls according to Moustafa et al. (2016) with some modification. The observation was carried out in an experimental room equipped with a dim red light at 60 min intervals during scotophase, from 8:00 till 16:00. Data of 9 females (cumulated for 5 days), for each concentration was recorded. Each female was deemed calling or non-calling based on PG protrudence $($ calling $=$ protruded $P G$; non-calling $=\mathrm{a} P \mathrm{PG}$ that was not visible).

\section{Analysis of pheromone blends}

\section{Extraction of pheromone gland}

For pheromone blend analysis, a pooled extract of 4 or 5 PGs was prepared. The glands were excised from D2 old virgin females between hours 2-3 of scotophase and extracted for an hour at room temperature in approximately $50 \mu \mathrm{L}$ of $n$-hexane. The samples were transferred to conical glass inserts, then placed into $1.5 \mathrm{~mL}$ vials [suitable for gas-chromatography (GC) mass-spectrometry (MS) analysis], and a $500 \mathrm{ng} / 5 \mu \mathrm{L}$ internal standard (tridecyl acetate; 13:OAc) was added before sealing with a Teflon-lined screw cap. The vials were stored at $-30^{\circ} \mathrm{C}$ until analysis.

Pupation percentage $=$ Number of pupae/Total number of alive larvae after treatment $* 100$

Emergence percentage $=$ Number of moths/Total number of pupae $* 100$.

\section{Fecundity and fertility}

After the 2 nd instar larvae were treated with the $\mathrm{LC}_{10}$ and $\mathrm{LC}_{50}$ of both insecticides, the emerged adults were grouped as 5 females and 7 males (conferring to one replicate) as in an earlier similar study in M. brassicae (Moustafa et al. 2016). The groups were transferred into glass jars (1 L), placed underneath a white paper, and the jar covered with a fine mesh screen. Adults were fed as described above. Three replicates for each sublethal $\mathrm{LC}_{10}$ and $\mathrm{LC}_{50}$ concentrations were used. Egg batches were counted daily to day 6 (D6),

\section{GC-mass spectrometry analysis}

Measurements were carried out on an Agilent (Santa Clara, California, USA) $6890 \mathrm{GC}$ coupled to a 5973 MS system. The injector temperature was $220^{\circ} \mathrm{C}$, the injection volume was $1 \mu \mathrm{L}$ in splitless mode, and the purge flow was $20 \mathrm{~mL} /$ min. Carrier gas of Helium 6.0 was used at the column flow rate of $1 \mathrm{~mL} / \mathrm{min}$ in constant linear velocity mode. The separation was performed on an Agilent J\&W VF WAXms $(60 \mathrm{~m} \times 0.25 \mathrm{~mm} \times 0.25 \mu \mathrm{m})$ polar capillary column. The heat program for separation started with a $1 \min 50{ }^{\circ} \mathrm{C}$ 
hold, then increased by $20^{\circ} \mathrm{C} / \mathrm{min}$ to $90^{\circ} \mathrm{C}$, then increased by $10{ }^{\circ} \mathrm{C} / \mathrm{min}$ to $190{ }^{\circ} \mathrm{C}$ and finally by $4{ }^{\circ} \mathrm{C} / \mathrm{min}$ to $240{ }^{\circ} \mathrm{C}$ and held for $5 \mathrm{~min}$. As a post-run function, the temperature was raised to $245^{\circ} \mathrm{C}$ and held for $3 \mathrm{~min}$ before returning to starting conditions. For mass spectrometric detection, the source temperature was set to $230{ }^{\circ} \mathrm{C}$ while the quadrupole temperature was held at $150{ }^{\circ} \mathrm{C}$. Positive electron ionization (EI+) was used with a standard electron energy level of $70 \mathrm{eV}$. The instrument was tuned using perfluorotributylamine according to the manufacturer's instructions. First, authentic standards were injected in scan mode to develop a Selected Ion Monitoring (SIM) method for quantitative mass spectrometric detection and to confirm compounds by their mass spectrum utilizing the NIST 17 mass spectral database. For quantitative measurements, the MS was operated in SIM mode at a cycle time of $20 \mathrm{~Hz}$. The following ions were monitored, the first ion stated was the best unique ion for quantitation, the second was the qualitative ion for calculating ion ratios for unambiguous identification: for the internal standard (13:OAc) with a Retention Time (RT): at $16.97 \mathrm{~min} \mathrm{~m} / \mathrm{z} 83,69$; for Z9-14:Ac (RT: $19.015 \mathrm{~min}$ ) $\mathrm{m} / \mathrm{z}$ 96, 86; for $E 11-14$ :Ac (RT: $19.05 \mathrm{~min}$ ) for Z11-14:Ac (RT: $19.25 \mathrm{~min}) \mathrm{m} / \mathrm{z} \mathrm{68,} \mathrm{82}$; for $(Z, E)$ 9,12-14:Ac (RT: $20.19 \mathrm{~min}$ ) and for $(Z, E)$ 9,11-14:Ac (RT: $21.25 \mathrm{~min}) \mathrm{m} / \mathrm{z}$ 67, 79. Agilent Enhanced MSD ChemStation software was used to set the GC and MS parameters. For quantitative evaluation, Mass Hunter Workstation Quantitative Analysis B.09.00 software was used.

\section{Activity of detoxifying enzymes}

\section{Sample preparations}

At 4 days post-treatment of 2 nd instar $S$. littoralis larvae were weighted and stored at $-40{ }^{\circ} \mathrm{C}$ until biochemical analysis.

\section{Mixed function oxidases (MFO) assay}

The MFO activity was determined according to Hansen and Hodgson (1971). Treated and untreated larvae were homogenized in ice-cold $0.1 \mathrm{M}$ phosphate buffer $(\mathrm{pH} 7.8)$ then centrifuged at $15,000 \mathrm{~g}$ at $4{ }^{\circ} \mathrm{C}$ for $15 \mathrm{~min}$. A hundred $\mu \mathrm{L}$ of $2 \mathrm{mM}$ p-NA solution and $90 \mu \mathrm{L}$ of the supernatant were added at $27{ }^{\circ} \mathrm{C}$ for $2 \mathrm{~min}$, and then $10 \mu \mathrm{L}$ of $9.6 \mathrm{mM}$ NADPH were added. The optical density (OD) was recorded at $405 \mathrm{~nm}$ for $10 \mathrm{~min}$ by Vmax kinetic microplate reader (Molecular Devices).

\section{Carboxylesterase (CarE) assays}

The activity of CarE (including; $\alpha$ - and $\beta$ - esterase) was determined according to Van Asperen (1962) modified by
Cao et al. (2008). Larvae were homogenized in phosphate buffer (0.1 M, pH 7.0) and centrifuged at 12,000 $g$ on $4{ }^{\circ} \mathrm{C}$ for $15 \mathrm{~min}$. A $50 \mu \mathrm{L}$ aliquot of the supernatant was incubated with $50 \mu \mathrm{L}$ of $(30 \mathrm{mM})$ alpha $(\alpha)$ or beta ( $(3)$ - naphthyl acetate at $30{ }^{\circ} \mathrm{C}$ for $15 \mathrm{~min}$ to evaluate $\alpha$ - and $\beta$ - esterase activities, respectively. The reaction was stopped by adding $50 \mu \mathrm{L}$ of stop solution 2 Fast Blue RR (1\%): sodium dodecyl sulphate (5\%). The color change was measured at $600 \mathrm{~nm}$ for hydrolysis of $\alpha$-naphthyl acetate and at $550 \mathrm{~nm}$ of hydrolysis of ß-naphthyl acetate by V-530 UV/Vis Spectrophotometer (JASCO Corporation). Bradford Coomassie brilliant blue assay and $\alpha$ - and $\beta$ - naphthyl acetate standard curves were used to calculate the mean levels of enzyme activity.

\section{Measurement of glutathione S-transferase (GST) activity}

GST activity was determined as described by Habing et al. (1974). The larvae were homogenized in $0.1 \mathrm{M}$ phosphate buffer ( $\mathrm{pH}$ 6.5) and centrifuged at $12,000 \mathrm{~g}$ on $4{ }^{\circ} \mathrm{C}$ for $15 \mathrm{~min}$. The reaction solution contained $100 \mu \mathrm{L}$ enzyme stock solution, $10 \mu \mathrm{L} 30 \mathrm{mM}$ CDNB, and $10 \mu \mathrm{L} 50 \mathrm{mM}$ $\mathrm{GSH}$, which was measured at $430 \mathrm{~nm}$ on $25^{\circ} \mathrm{C}$ for $3 \mathrm{~min}$ by V-530 UV/Vis spectrophotometer.

\section{Statistical analysis}

Probit analysis (EPA Probit analysis program, version 1.5) was used to estimate the lethal and sublethal values $\left(\mathrm{LC}_{10}\right.$ and $\mathrm{LC}_{50}$ ) of chlorantraniliprole and indoxacarb on different instar S. littoralis larvae at 4 days post-exposure. Further data analyses were performed using one-way ANOVA (SAS 2001) followed by Tukey's Honestly Significant Different.

\section{Results}

\section{Lethal effects of chlorantraniliprole and indoxacarb on different larval instars}

The results of feeding the various $S$. littoralis larval instars on castor bean leaves treated with different concentrations of chlorantraniliprole or indoxacarb are presented in Tables 1 and 2 , respectively. The chlorantraniliprole $\mathrm{LC}_{10}$, and $\mathrm{LC}_{50}$ values ranged from 0.014 to 0.323 , and 0.06 to $1.07 \mathrm{mg} / \mathrm{L}$, respectively for the 1 st to 6th instars, while the $\mathrm{LC}_{90}$ values were 0.34 to $3.54 \mathrm{mg} / \mathrm{L}$ (Table 1 ). In contrast, the $\mathrm{LC}_{10}$, and $\mathrm{LC}_{50}$ values of indoxacarb were between 0.001 to 0.055 , and 0.005 to $0.81 \mathrm{mg} / \mathrm{L}$, respectively for the 1 st to 6 th instars, while the $\mathrm{LC}_{90}$ values were from 0.021 to $11.87 \mathrm{mg} / \mathrm{L}$ (Table 2). 

laboratory-reared $S$. littoralis larvae to chlorantraniliprole
Table 1 Susceptibility of

\begin{tabular}{lllll}
\hline Larval instar & $\begin{array}{l}\mathrm{LC}_{10}(\mathrm{mg} / \mathrm{L})^{\mathrm{a}} \\
(95 \% \text { Confidence limit })\end{array}$ & $\begin{array}{l}\mathrm{LC}_{50}(\mathrm{mg} / \mathrm{L})^{\mathrm{b}} \\
(95 \% \text { Confidence limit })\end{array}$ & $\begin{array}{l}\mathrm{LC}_{90}(\mathrm{mg} / \mathrm{L})^{\mathrm{c}} \\
(95 \% \text { Confidence limit})\end{array}$ & Slope $\pm \mathrm{SE}$ \\
\hline 1st & $0.014(0.004-0.023)$ & $0.06(0.044-0.145)$ & $0.34(0.157-2.981)$ & $1.82 \pm 0.284$ \\
2nd & $0.019(0.015-0.024)$ & $0.09(0.075-0.114)$ & $0.41(0.286-0.729)$ & $1.91 \pm 0.190$ \\
3rd & $0.024(0.01-0.10)$ & $0.20(0.001-0.479)$ & $1.67(0.646-2.429)$ & $1.39 \pm 0.404$ \\
4th & $0.058(0.039-0.078)$ & $0.23(0.195-0.270)$ & $0.93(0.765-1.214)$ & $2.12 \pm 0.187$ \\
5th & $0.175(0.70-0.288)$ & $0.76(0.554-0.970)$ & $3.37(2.445-5.883)$ & $1.99 \pm 0.418$ \\
6th & $0.323(0.152-0.483)$ & $1.07(0.809-1.360)$ & $3.54(2.529-6.499)$ & $2.46 \pm 0.319$ \\
\hline
\end{tabular}

First to sixth instar larvae were treated with five different concentrations (ranging from 0.0078 to $4 \mathrm{mg} / \mathrm{L}$ ) of chlorantraniliprole by the leaf dipping technique. After $24 \mathrm{~h}$ they were fed with untreated fresh castor leaves. Larvae were monitored throughout development. The test was performed in four replicates $(n=25)$. For concentrations see Supplementary material

${ }^{\mathrm{a}} \mathrm{LC}_{10}$ : concentration causing $10 \%$ mortality

${ }^{\mathrm{b}} \mathrm{LC}_{50}$ : concentration causing $50 \%$ mortality

${ }^{\mathrm{c}} \mathrm{LC}_{90}$ : concentration causing $90 \%$ mortality

Table 2 Susceptibility of laboratory-reared $S$. littoralis larvae to indoxacarb

\begin{tabular}{llllr}
\hline Larval instar & $\begin{array}{l}\mathrm{LC}_{10}(\mathrm{mg} / \mathrm{L})^{\mathrm{a}} \\
(95 \% \text { Confidence limit })\end{array}$ & $\begin{array}{l}\mathrm{LC}_{50}(\mathrm{mg} / \mathrm{L})^{\mathrm{b}} \\
(95 \% \text { Confidence limit })\end{array}$ & $\begin{array}{l}\mathrm{LC}_{90}(\mathrm{mg} / \mathrm{L})^{\mathrm{c}} \\
(95 \% \text { Confidence limit })\end{array}$ & Slope $\pm \mathrm{SE}$ \\
\hline 1st & $0.001(0.001-0.002)$ & $0.005(0.004-0.006)$ & $0.021(0.014-0.039)$ & $2.00 \pm 0.303$ \\
2nd & $0.001(0.001-0.002)$ & $0.01(0.008-0.020)$ & $0.17(0.084-1.260)$ & $1.15 \pm 0.278$ \\
3rd & $0.003(0.001-0.010)$ & $0.03(0.017-0.057)$ & $0.44(0.240-2.140)$ & $1.20 \pm 0.286$ \\
4th & $0.016(0.002-0.040)$ & $0.13(0.062-0.188)$ & $1.04(0.660-2.820)$ & $1.41 \pm 0.304$ \\
5th & $0.041(0.021-0.063)$ & $0.31(0.251-0.380)$ & $2.43(1.735-3.952)$ & $1.44 \pm 0.150$ \\
6th & $0.055(0.011-0.124)$ & $0.81(0.547-1.145)$ & $11.87(5.779-50.448)$ & $1.09 \pm 0.199$ \\
\hline
\end{tabular}

First to sixth instar larvae were treated with five different concentrations (ranging from 0.0019 to $4 \mathrm{mg} / \mathrm{L}$ ) of indoxacarb. Further conditions as in Table 1

${ }^{a} \mathrm{LC}_{10}$ : concentration causing $10 \%$ mortality

${ }^{\mathrm{b}} \mathrm{LC}_{50}$ : concentration causing $50 \%$ mortality

${ }^{\mathrm{c}} \mathrm{LC}_{90}$ : concentration causing $90 \%$ mortality

\section{Sublethal effects of chlorantraniliprole and indoxacarb on development}

Both tested insecticides significantly increased the larval and pupal duration (Table 3). Both insecticides decreased pupation rate at the concentration equivalent to $\mathrm{LC}_{50}$, while pupal weight significantly increased after the larvae were treated with the $\mathrm{LC}_{10}$ and $\mathrm{LC}_{50}$ of chlorantraniliprole and indoxacarb $\mathrm{LC}_{50}$ value. In contrast, there were no significant effects on sex ratio and emergence rate between the treated larvae and untreated larvae (Table 3).

\section{Fecundity and fertility}

Both insecticides showed no significant differences in the percentage of hatchability at all concentrations tested ( $\mathrm{LC}_{10}$ and $\mathrm{LC}_{50}$ equivalent) except for $\mathrm{LC}_{50}$ equivalent of indoxacarb compared to the control (Table 4). In contrast, there was no significant difference in the number of eggs laid by one female (fecundity) between treated and untreated larvae (Table 4).

\section{Calling behavior}

Calling activity was the most intense between the 2 nd (09:00) and 4th (11:00) hours of scotophase. Female calling behavior after treating 2 nd instar larvae of $S$. littoralis with both insecticides were $(24.42 \pm 4.1 \%)$ and $(31.08 \pm 8.1 \%)$ for chlorantraniliprole $\mathrm{LC}_{10},(19.98 \pm 2.2 \%)$ and $(22.20 \pm 7.8 \%)$ for chlorantraniliprole $\mathrm{LC}_{50}$, $(19.98 \pm 2.2 \%)$ and $(31.08 \pm 6.4 \%)$ for indoxacarb $\mathrm{LC}_{10}$, while $(13.32 \pm 2.2 \%)$ and $(17.76 \pm 4.4 \%)$ for indoxacarb $\mathrm{LC}_{50}$ at the 2 nd and 4 th hours of scotophase respectively, and clearly decreased towards the end of scotophase (Fig. 1). Overall, female calling behavior following exposure to the $\mathrm{LC}_{50}$ concentration of both insecticides compared to controls significantly decreased (50-60\%) (Fig. 1). 
Table 3 Effects of chlorantraniliprole and indoxacarb on development of S. littoralis from 2nd instar larvae to emergence

\begin{tabular}{|c|c|c|c|c|c|c|c|c|}
\hline \multirow[t]{3}{*}{ Treatments } & \multicolumn{8}{|l|}{ Mean \pm SE } \\
\hline & \multirow{2}{*}{$\begin{array}{l}\text { Larval dura- } \\
\text { tion (days)* }\end{array}$} & \multirow{2}{*}{$\begin{array}{l}\text { Pupation rate } \\
(\%)\end{array}$} & \multirow{2}{*}{$\begin{array}{l}\text { Pupal duration } \\
\text { (days)** }\end{array}$} & \multicolumn{2}{|l|}{ Pupal weight (g) } & \multicolumn{2}{|l|}{ Sex ratio } & \multirow[t]{2}{*}{ Emergence \% } \\
\hline & & & & Female & Male & Female & Male & \\
\hline \multicolumn{9}{|l|}{$\begin{array}{l}\text { Chlorant- } \\
\text { raniliprole }\end{array}$} \\
\hline $\mathrm{LC}_{10}$ & $17.99 \pm 1.27^{\mathrm{c}}$ & $98.26 \pm 1.71^{\mathrm{a}}$ & $8.59 \pm 0.84^{\mathrm{ab}}$ & $0.323 \pm 0.05^{\mathrm{a}}$ & $0.294 \pm 0.04^{\mathrm{a}}$ & $55.19 \pm 1.77^{\mathrm{a}}$ & $44.80 \pm 1.78^{\mathrm{a}}$ & $98.62 \pm 1.62^{\mathrm{a}}$ \\
\hline $\mathrm{LC}_{50}$ & $18.20 \pm 1.51^{\mathrm{c}}$ & $95.76 \pm 2.88^{\mathrm{cb}}$ & $8.78 \pm 0.87^{\mathrm{a}}$ & $0.318 \pm 0.05^{\mathrm{a}}$ & $0.290 \pm 0.05^{\mathrm{a}}$ & $50.64 \pm 5.26^{\mathrm{a}}$ & $49.32 \pm 5.27^{\mathrm{a}}$ & $95.63 \pm 3.14^{\mathrm{a}}$ \\
\hline \multicolumn{9}{|l|}{ Indoxacarb } \\
\hline $\mathrm{LC}_{10}$ & $18.79 \pm 0.08^{\mathrm{b}}$ & $93.20 \pm 0.97^{a b}$ & $10.37 \pm 0.08^{\mathrm{a}}$ & $0.296 \pm 0.004^{\mathrm{b}}$ & $0.269 \pm 0.003^{b}$ & $46.52 \pm 6.22^{\mathrm{a}}$ & $53.47 \pm 6.22^{\mathrm{a}}$ & $95.72 \pm 1.84^{\mathrm{a}}$ \\
\hline $\mathrm{LC}_{50}$ & $19.6 \pm 0.11^{\mathrm{a}}$ & $92.74 \pm 0.72^{\mathrm{b}}$ & $10.38 \pm 0.90^{\mathrm{a}}$ & $0.354 \pm 0.006^{\mathrm{a}}$ & $0.317 \pm 0.005^{\mathrm{a}}$ & $48.68 \pm 2.42^{\mathrm{a}}$ & $51.31 \pm 2.42^{\mathrm{a}}$ & $95.97 \pm 0.80^{\mathrm{a}}$ \\
\hline
\end{tabular}

Second instar larvae were treated with different $\left(\mathrm{LC}_{10}\right.$ and $\left.\mathrm{LC}_{50}\right)$ sublethal concentrations of chlorantraniliprole and indoxacarb. After $24 \mathrm{~h}$ they were fed with untreated fresh castor leaves ( $n=25$ in four replicates)

Values marked with the same letters are not significantly different $(p>0.05$ : Tukey's Honestly Significant Different) between control and each treatment of both chlorantraniliprole and indoxacarb

*Number of days from 2nd instar larvae till pupation

**Number of days from the pupation till the emergence

Table 4 Mean fecundity and hatchability percentage $( \pm \mathrm{SE})$ of $S$. littoralis females

\begin{tabular}{lll}
\hline Treatments & Fecundity* & Hatchability \%** \\
\hline Control & $573.73 \pm 28.92^{\mathrm{a}}$ & $92.95 \pm 2.17^{\mathrm{a}}$ \\
Chlorantraniliprole & & \\
$\mathrm{LC}_{10}$ & $577.44 \pm 61.62^{\mathrm{a}}$ & $75.13 \pm 7.06^{\mathrm{ab}}$ \\
$\mathrm{LC}_{50}$ & $511.13 \pm 86.07^{\mathrm{a}}$ & $67.76 \pm 5.93^{\mathrm{ab}}$ \\
Indoxacarb & & \\
$\mathrm{LC}_{10}$ & $533.09 \pm 104.34^{\mathrm{a}}$ & $67.78 \pm 6.66^{\mathrm{ab}}$ \\
$\mathrm{LC}_{50}$ & $352.15 \pm 8.98^{\mathrm{a}}$ & $62.73 \pm 7.48^{\mathrm{b}}$ \\
\hline
\end{tabular}

Second instar larvae were treated with different sublethal concentrations $\left(\mathrm{LC}_{10}\right.$ and $\left.\mathrm{LC}_{50}\right)$ of chlorantraniliprole and indoxacarb. After $24 \mathrm{~h}$ they were fed with untreated fresh castor leaves. Three replicates ( 5 females +7 males) were assayed at each concentration

Values marked with the same letters are not significantly different ( $p>0.05$ : Tukey's Honestly Significant Different) between control and each treatment of both chlorantraniliprole and indoxacarb

*Fecundity was estimated by counting the eggs from the first day till the sixth day (total number of eggs laid by one female)

**Hatchability is calculated by counting the emerged larvae from collected eggs batches

\section{Pheromone production}

Based on the described GC-MS methodology we determined the changes of five pheromone components including the two most decisive ones as $(Z, E) 9,12-14$ :Ac and $(Z, E) 9,11-14$ :Ac. On Table 5, the five different blend component amounts (in $\mathrm{ng} / \mathrm{PG}$ ) are listed according to their retention times. Treatments did not result in significant differences in the amount of pheromone components in comparison to controls, except in the case of chlorantraniliprole $\mathrm{LC}_{50}$, for a major component $(Z, E) 9,12-14$ :Ac and indoxacarb $\mathrm{LC}_{10}$ equivalent $\mathrm{Z9}-14$ : Ac, which is a minor component.

\section{Detoxification enzyme activities}

The activity of MFO was much higher (15-fold) at a sublethal $\mathrm{LC}_{10}$ concentration of indoxacarb compared with that of control, but was only threefold higher at the $\mathrm{LC}_{50}$ (Table 6). In contrast, $\mathrm{MFO}$ activities increased to 3.9-fold at $\mathrm{LC}_{10}$ and 4.3 -fold at $\mathrm{LC}_{50}$ of the chlorantraniliprole. The higher $\alpha$-esterase activity was found in all treatments except for the indoxacarb $\mathrm{LC}_{50}$ value (Table 6). In addition, the chlorantraniliprole $\mathrm{LC}_{50}$ and indoxacarb $\mathrm{LC}_{10}$ concentrations significantly increased the $\beta$-esterase activity (Table 6). Likewise, GST activity was elevated at chlorantraniliprole $\mathrm{LC}_{50}$ and indoxacarb $\mathrm{LC}_{10}$ concentrations (Table 6).

\section{Discussion}

Chlorantraniliprole and indoxacarb are promising alternative compounds that could be effectively used in crop protection. Understanding the effects of any pesticide is important to implement appropriate resistance management strategies or to reduce the pesticide treatment thresholds before control failures occur (Liu et al. 2011). This study aimed to advance our knowledge of the insecticidal activity and the latent effects of chlorantraniliprole and indoxacarb against S. littoralis. 


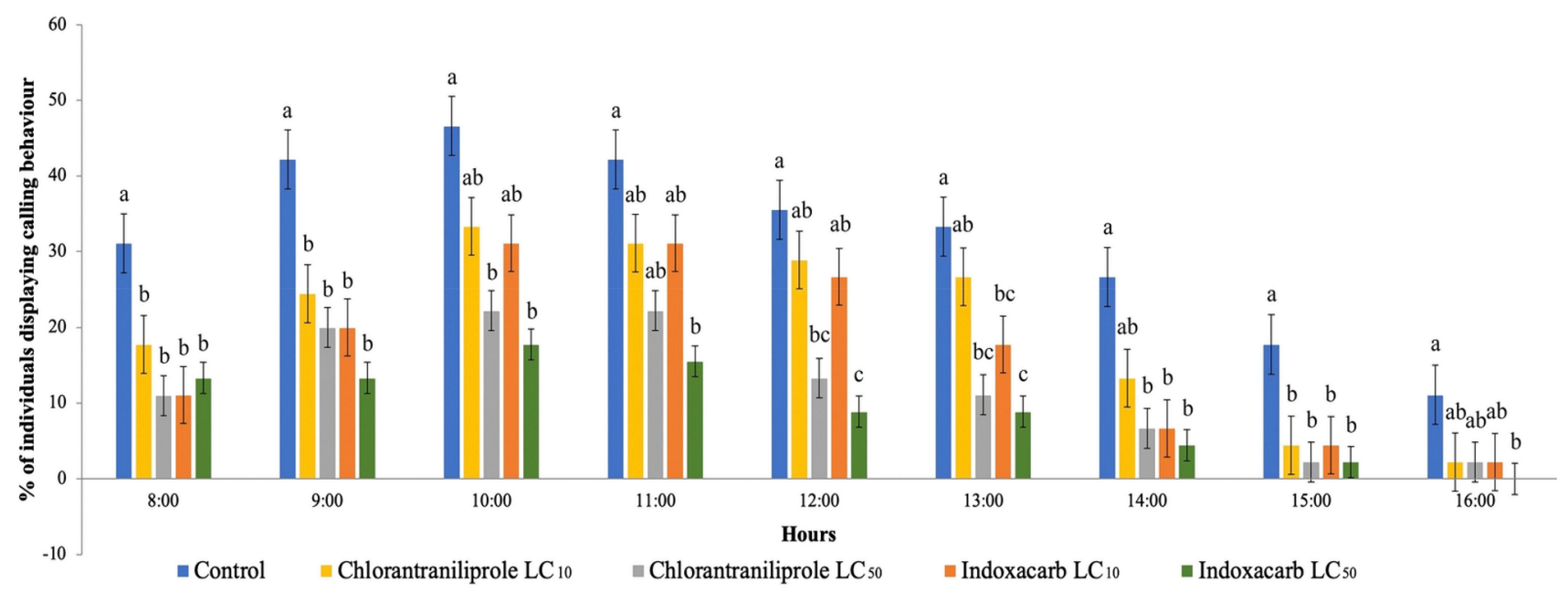

Fig. 1 Calling behavior of adult $S$. littoralis females. Percentage (charts represent means \pm SE; $n=9$ recorded from D1 till D5) of $S$. littoralis females exhibiting calling behavior in scotophase $(8 \mathrm{~h}$, from 8:00 till 16:00.). Females were derived from 2 nd instar larvae fed with leaves treated with sublethal concentration $\mathrm{LC}_{10}$ and $\mathrm{LC}_{50}$ equivalent of chlorantraniliprole or indoxacarb. Controls are larvae fed with untreated leaves. One-way ANOVA followed by Tukey's honestly significant difference (HSD) post hoc test was performed among the control and each treatment of both insecticides at each time point. In each time point, values marked with the same letters are not significantly different ( $p>0.05$ : Tukey's HSD post hoc test)

Table 5 Pheromone production in S. littoralis females

\begin{tabular}{|c|c|c|c|c|c|}
\hline \multirow[t]{2}{*}{ Treatments } & \multicolumn{5}{|c|}{ Mean titer $(\mathrm{ng}) /$ female $(\mathrm{PG}) \pm \mathrm{SE}(\mathrm{CV} \%)$} \\
\hline & Z9-14:Ac & E11-14:Ac & Z11-14:Ac & $(Z, E)$ 9,12-14:Ac & $(Z, E)$ 9,11-14:Ac \\
\hline Control & $1.75 \pm 0.04^{\mathrm{a}}(0.022)$ & $1.10 \pm 0.04^{\mathrm{a}}(0.036)$ & $0.57 \pm 0.03^{\mathrm{a}}(0.052)$ & $4.27 \pm 0.15^{\mathrm{a}}(0.035)$ & $3.14 \pm 0.08^{\mathrm{a}}(0.025)$ \\
\hline \multicolumn{6}{|c|}{ Chlorantraniliprole } \\
\hline $\mathrm{LC}_{10}$ & $1.57 \pm 0.08^{\mathrm{a}}(0.05)$ & $1.03 \pm 0.21^{\mathrm{a}}(0.199)$ & $0.51 \pm 0.09^{\mathrm{a}}(0.169)$ & $3.96 \pm 0.92^{\mathrm{ab}}(0.298)$ & $3.26 \pm 0.29^{\mathrm{a}}(0.089)$ \\
\hline $\mathrm{LC}_{50}$ & $1.42 \pm 0.37^{\mathrm{ab}}(0.264)$ & $0.78 \pm 0.19^{\mathrm{a}}(0.243)$ & $0.40 \pm 0.10^{\mathrm{a}}(0.250)$ & $1.42 \pm 0.64^{\mathrm{b}}(0.450)$ & $2.60 \pm 0.52^{\mathrm{a}}(0.20)$ \\
\hline \multicolumn{6}{|l|}{ Indoxacarb } \\
\hline $\mathrm{LC}_{10}$ & $1.18 \pm 0.07^{\mathrm{b}}(0.035)$ & $0.72 \pm 0.09^{\mathrm{a}}(0.123)$ & $0.32 \pm 0.05^{\mathrm{a}}(0.128)$ & $2.74 \pm 0.84^{\mathrm{ab}}(0.306)$ & $2.30 \pm 0.26^{\mathrm{a}}(0.102)$ \\
\hline $\mathrm{LC}_{50}$ & $1.61 \pm 0.16^{\mathrm{ab}}(0.106)$ & $0.84 \pm 0.07^{\mathrm{a}}(0.083)$ & $0.44 \pm 0.04^{\mathrm{a}}(0.088)$ & $2.64 \pm 0.61^{\mathrm{ab}}(0.286)$ & $2.57 \pm 0.29^{\mathrm{a}}(0.113)$ \\
\hline
\end{tabular}

Mean pheromone blend component titers ng/female \pm SE (CV\%, SE/Mean, $n=4-5$ pheromone glands /sample in three replicates) of 2-day-old $S$. littoralis females (at the $2^{\text {nd }}-3$ rd hour of scotophase) treated as 2 nd instar larvae with $\mathrm{LC}_{10}$ and $\mathrm{LC}_{50}$ values of chlorantraniliprole or indoxacarb. After $24 \mathrm{~h}$ they were fed with untreated fresh castor leaves

Values marked with the same letters are not significantly different ( $p>0.05$ : Tukey's Honestly Significant Different) between control and each treatment of both chlorantraniliprole and indoxacarb

$\mathrm{CV} \%=\mathrm{SE} / \mathrm{Mean}$

Our results indicate that the susceptibility of $S$. littoralis to chlorantraniliprole and indoxacarb decreased with larval age; 6th instar larvae had much higher tolerance levels compared to 1 st and 2nd instars (Tables 1,2 ). The susceptibility of an organism to a particular chemical is influenced by several factors including size, nutrition and physiological status (Liu and Trumble 2005; Stark and Rangus 1994; Yin et al. 2008). The sensitivities of early and late instar as 6th instar larvae tolerance were significantly greater than that of 1 st instars $(\sim 283.3$-fold for chlorantraniliprole and 162-fold for indoxacarb). Similarly,
Gamil et al. (2011) found that the 2nd instar larvae of $S$. littoralis were more susceptible than 4th instar to indoxacarb. Spodoptera exigua Hübner (Lepidoptera: Noctuidae) laboratory strain was found to be more susceptible to chlorantraniliprole $\left(\mathrm{LC}_{50}=0.014 \mathrm{mg} / \mathrm{L}\right)$ than 18 different field strains in China (Lai and Su 2011). A laboratory strain of $H$. armigera was likewise more tolerant to indoxacarb $\left(\mathrm{LC}_{50}=0.147 \mu \mathrm{g} / \mathrm{mL}\right)$ than chlorantraniliprole $\left(\mathrm{LC}_{50}=0.0147 \mu \mathrm{g} / \mathrm{mL}\right)($ Bird 2015). Recently, Cui et al. (2018) reported an $\mathrm{LC}_{50}$ value of $5.93 \mathrm{mg} / \mathrm{L}$ for indoxacarb in 3rd instar H. armigera larvae, which is remarkably high. 
Table 6 Detoxification enzyme activities in S. littoralis larvae

\begin{tabular}{|c|c|c|c|c|}
\hline \multirow[t]{2}{*}{ Treatments } & \multirow{2}{*}{$\begin{array}{l}\mathrm{MFO}(\mathrm{mOD} / \mathrm{min} / \\
\mathrm{mg} \text { protein })\end{array}$} & \multicolumn{2}{|c|}{ Carboxylesterase (mol/min/mg protein) } & \multirow{2}{*}{$\begin{array}{l}\text { GST (mmol/ } \\
\mathrm{min} / \mathrm{mg} \text { pro- } \\
\text { tein) }\end{array}$} \\
\hline & & $\alpha$-esterase & $\beta$-esterase & \\
\hline Control & $0.36 \pm 0.02^{\mathrm{d}}$ & $0.0026 \pm 0.00025^{\mathrm{c}}$ & $0.202 \pm 0.017^{\mathrm{c}}$ & $1.78 \pm 0.04^{\mathrm{cd}}$ \\
\hline \multicolumn{5}{|c|}{ Chlorantraniliprole } \\
\hline $\mathrm{LC}_{10}$ & $1.39 \pm 0.04^{\mathrm{b}}$ & $0.0045 \pm 0.00017^{\mathrm{b}}$ & $0.242 \pm 0.017^{\mathrm{c}}$ & $1.59 \pm 0.08^{\mathrm{d}}$ \\
\hline $\mathrm{LC}_{50}$ & $1.53 \pm 0.86^{\mathrm{b}}$ & $0.0072 \pm 0.00020^{\mathrm{a}}$ & $0.488 \pm 0.006^{\mathrm{a}}$ & $3.75 \pm 0.16^{\mathrm{b}}$ \\
\hline \multicolumn{5}{|l|}{ Indoxacarb } \\
\hline $\mathrm{LC}_{10}$ & $5.72 \pm 0.13^{\mathrm{a}}$ & $0.0037 \pm 0.00019^{\mathrm{b}}$ & $0.329 \pm 0.003^{\mathrm{b}}$ & $4.85 \pm 0.05^{\mathrm{a}}$ \\
\hline $\mathrm{LC}_{50}$ & $0.94 \pm 0.05^{\mathrm{c}}$ & $0.0014 \pm 0.00023^{\mathrm{d}}$ & $0.206 \pm 0.027^{\mathrm{c}}$ & $2.10 \pm 0.17^{\mathrm{c}}$ \\
\hline
\end{tabular}

Mixed Function Oxidases (MFO), Carboxylesterase ( $\alpha$ - and $\beta$ - esterase) and Glutation S-transferase (GST) activities of $S$. littoralis following treatment as 2 nd instar larvae with sublethal $\left(\mathrm{LC}_{10}\right.$ and $\left.\mathrm{LC}_{50}\right)$ concentrations of chlorantraniliprole and indoxacarb. After $24 \mathrm{~h}$ they were fed with untreated fresh castor leaves. Samples were taken four days post-treatment. For each enzyme assay five replicates/concentration were used

Enzyme activity is showed as mean $\pm \mathrm{SE}$ and means followed by different letters are significantly different by Tukey's honestly significant different $(p<0.05)$ between control and each treatment of both chlorantraniliprole and indoxacarb
It is a common phenomenon that insects are exposed to sublethal concentrations of insecticides because of their degradation after initial application in crops. So, when larvae are exposed to sublethal concentrations of chlorantraniliprole and indoxacarb it models such circumstances, and well demonstrated that developmental rates had significantly decreased and prolonged the larval and pupal stages (Table 3). These results are in agreement with ElDewy (2017) who found that both insecticides significantly increased the larval duration after 4th instar larvae of $S$. littoralis were treated with $\mathrm{LC}_{25}$ value. Also, both insecticides have been found to inhibit $P$. xylostella development (Guo et al. 2013; Wang et al. 2011). These findings on life span/length and rate of development that occur after larval insecticide exposures are consistent with Yin et al. (2008), and Liu and Trumble (2005) in both spices of $P$. xylostella and Bactericera cockerelli (Šulc) (Hemiptera: Triozidae) respectively. No significant differences in the eggs that hatched were found following the exposure of 2nd instar larvae to $\mathrm{LC}_{10}$ and $\mathrm{LC}_{50}$ values of either chlorantraniliprole or indoxacarb. This is in accordance with the study of Mahmoudvand et al. (2011) who proved that indoxacarb when tested individually on $P$. xylostella didn't significantly increase egg mortality.

Female adult calling behavior in non-treated control was similar to that described earlier (Dunkelblum et al. 1987; Silvegren et al. 2005). As shown in Fig. 1, intensive calling behavior occurs between the 2 nd and 4 th hours in scotophase, but then gradually drops to around $10 \%$ at the end of scotophase. A similar drastic drop was observed M. brassicae following treatment with sublethal doses of spinosad or emamectin benzoate (Moustafa et al. 2016). For P. xylostella females, 3rd instar larvae treated with a sublethal dose of indoxacarb resulted in robust calling behavior during the initial scotophase, but decreased with following scotophases (Wang et al. 2011).

Sex pheromone production is tightly coordinated with physiological events that are under hormonal and neuronal control. For moths, pheromone biosynthesis is typically regulated by a neuropeptide, pheromone biosynthesis activating neuropeptide (PBAN) (Bloch et al. 2013; Hull and Fónagy 2019). Unlike most Noctuids, pheromone biosynthesis peaks in S. littoralis during the 2nd to 3rd hours of scotophase, which correlates with their calling activity (Silvegren et al. 2005) (Fig. 1). In earlier studies, S. littoralis pheromone biosynthesis and production were reported as ng pheromone/PG and the measured amount at peak production of the main component, $(Z, E) 9,11-14$ :Ac, was around 7-8 ng/ PG (Dunkelblum et al. 1987; Marco et al. 1996;). In our study, we obtained $3.26 \pm 0.29 \mathrm{ng} / \mathrm{PG}$ of $(Z, E) 9,11-14: \mathrm{Ac}$ and $3.96 \pm 0.92 \mathrm{ng} / \mathrm{PG}$ of $(Z, E) 9,12-14$ :Ac (Table 5), respectively, with $\mathrm{LC}_{10}$ equivalent chlorantraniliprole due to using a very sensitive heat program for the developed SIM method, which two components when summed are comparable to that previously reported (Dunkelblum et al. 1987; Marco et al. 1996;). The results regarding pheromone production in $M$. brassicae had significant differences also in comparison to controls when 2 nd instar larvae were treated with different sublethal concentrations of spinosad or emamectin benzoate (Moustafa et al. 2016).

Sublethal concentrations of insecticides could prompt detoxification enzymes such as GSTs that are responsible for insecticide resistance. Increased MFO and GST activities were detected in both insecticide treatments (Table 6). These results indicated that MFO and GST are closely related to chlorantraniliprole and indoxacarb detoxification enzymes system. However, no significant increase in alpha-esterase activity when exposed to indoxacarb $\mathrm{LC}_{50}$. This finding may 
be related to the activation of indoxacarb converting it into a decarbomethoxylated metabolite as well demonstrated in Periplaneta americana (Linnaeus) (Blattodea: Blattidae) (Gondhalekar et al. 2016; Zhao et al. 2005). In contrast, GST activity was increased $24 \mathrm{~h}$ post-treatment in $3 \mathrm{rd}$ instar $H$. armigera larvae exposed to $\mathrm{LC}_{30}$ value of indoxacarb and hexaflumuron (Vojoudi et al. 2017), whereas CarE and GST activities were reduced after 3 days post-treatment. Sial et al. (2011) proposed that the chlorantraniliprole resistance strain of Choristoneura rosaceana (Harris) (Lepidoptera: Tortricidae) had higher CarE activity after 9 generations of selection. In contrast, the activity of MFO enzymes in 9 resistant field populations of $S$. litura was significantly higher compared with the susceptible strain, while only 2 populations had higher activities of CarE and GST (Su et al. 2012).

\section{Conclusion}

Both chlorantraniliprole and indoxacarb showed high toxicity against $S$. littoralis larvae. The lethal and sublethal exposures to these insecticides significantly affected the larval and pupal developmental period. Additionally, among the detoxification enzymes, MFO, and GST activities increased. However, insecticide resistance development could reduce the efficiency of the two insecticides. Consequently, resistance monitoring should be conducted to generate the information needed for establishing sustainable and effective management strategies for $S$. littoralis that utilize either chlorantraniliprole or indoxacarb.

Acknowledgements This research was funded by the Science \& Technology Development Fund (STDF), Egypt (Project ID; 33353). Author P. B. M. is thankful for the Janos Bolyai Grant fellowship. We would like to express our special thanks to Dr. Ibrahim S. Ahmed (Faculty of Agriculture, Cairo University, Egypt), Dr. József Fodor (Plant Protection Institute of CAR, Budapest, Hungary) and Dr. J. Joe Hull (USDA, ARS, Maricopa AZ, U.S.A.) for improving the manuscript considerably, including English grammar and styles.

\section{References}

Ando T, Inomata S, Yamamoto M (2004) Lepidopteran sex pheromones. Top Curr Chem 239:51-96

Aydin MH, Gürkan MO (2006) The efficacy of spinosad on different strains of Spodoptera littoralis (Boisduval) (Lepidoptera: Noctuidae). Turk J Biol 30:5-9

Bentley KS, Fletcher JL, Woodward MD (2010) Chlorantraniliprole: an insecticide of the anthranilic diamide class. In: Krieger R (ed) Hayes' handbook of pesticide toxicology. Academic Press, London, pp 2232-2242

Bird LJ (2015) Baseline susceptibility of Helicoverpa armigera (Lepidoptera: Noctuidae) to indoxacarb, emamectin benzoate, and chlorantraniliprole in Australia. J Econ Entomol 108:294-300

Bloch G, Hazan E, Rafaeli A (2013) Circadian rhythms and endocrine functions in adult insects. J Insect Physiol 59:56-69
Campion DG, Hunter-Jones P, McVeigh LJ, Hall DR, Lester R, Nesbitt BF (1980) Modification of the attractiveness of the primary pheromone component of the Egyptian cotton leafworm, Spodoptera littoralis (Boisduval) (Lepidoptera: Noctuidae), by secondary pheromone components and related chemicals. Bull Entomol Res 70:417-434

Cao C, Zhang J, Gao X, Liang P, Guo H (2008) Overexpression of carboxylesterase gene associated with organophosphorous insecticide resistance in cotton aphids, Aphis gossypii (Glover). Pestic Biochem Physiol 90:175-180

Carter D (1984) Pest lepidoptera of Europe with special reference to the British Isles. Junk Publishers, Dordrecht

Crava CM, Bruetting C, Baldwin IT (2016) Transcriptome profiling reveals differential gene expression of detoxification enzymes in a hemimetabolous tobacco pest after feeding on jasmonate-silenced Nicotiana attenuata plants. BMC Genom 17:1005

Cui L, Wang Q, Qi H, Wang Q, Yuan H, Ru C (2018) Resistance selection of indoxacarb in Helicoverpa armigera (Hübner) (Lepidoptera: Noctuidae): cross-resistance, biochemical mechanisms and associated fitness costs. Pest Manag Sci 74:2636-2644

Desneux N, Decourtye A, Delpuech JM (2007) The sublethal effects of pesticides on beneficial arthropods. Annu Rev Entomol 52:81-106

Dunkelblum E, Kehat M, Harel M, Gordon D (1987) Sexual behaviour and pheromone titre of the Spodoptera littoralis female moth. Entomol Exp Appl 44:241-247

El-Defrawi ME, Tappozada AT, Salama A, El-Khishen SA (1964) Toxicological studies on the Egyptian cotton leafworm prodenia litura F.II. Reversions of Toxaphene resistance in the Egyptian cotton leafworm. J Econ Entomol 18:265-267

El-Dewy MEH (2017) Influence of some novel insecticides on physiological and biological aspects of Spodoptera littoralis (Boisduval). Alex Sci Exchange J 38:250-258

El-Sheikh EA (2015) Comparative toxicity and sublethal effects of emamectin benzoate, lufenuron and spinosad on Spodoptera littoralis Boisd. (Lepidoptera: Noctuidae). Crop Prot 67:228-234

El-Sheikh ESAM, El-Saleh MA, Aioub AA, Desuky WM (2018) Toxic effects of neonicotinoid insecticides on a field strain of cotton leafworm, Spodoptera littoralis. Asian J Biol Sci 11:179-185

Gamal A, Abdel-Raof E, Hossam E (2009) Resistance stability to spinosad and abamectin in the cotton leafworm, Spodoptera littoralis (Bosid.). Resist Pest Manag Newslett 19:21-26

Gamil WE, Mariy FM, Youssef LA, Abdel Halim SM (2011) Effectof Indoxacarb on some biological and biochemical aspects of Spodoptera littoralis Boisd. larvae. Ann Agric Sci 6:121-126

Gondhalekar AD, Song C, Scharf ME (2011) Development of strategies for monitoring indoxacarb and gel bait susceptibility in the German cockroach (Blattodea: Blattellidae). Pest Manag Sci 67:262-270

Gondhalekar AD, Nakayasu ES, Silva I, Cooper B, Scharf ME (2016) Indoxacarb biotransformation in the German cockroach. Pestic Biochem Physiol 134:14-23

Guo L, Desneux N, Sonoda S, Liang P, Han P, Gao X-W (2013) Sublethal and transgenerational effects of chlorantraniliprole on biological traits of the diamondback moth, Plutella xylostella $\mathrm{L}$. Crop Prot 48:29-34

Habing WH, Pabst J, Jackoby WB (1974) Glutathione S transferases: the first enzymatic step in mercapturic acid formation. J Biol Chem 249:7130-7139

Hannig GT, Ziegler M, Marcon PG (2009) Feeding cessation effects of chlorantraniliprole, a new anthranilic diamide insecticide, in comparison with several insecticides in distinct chemical classes and mode-of-action groups. Pest Manag Sci 65:969-974

Hansen LG, Hodgson E (1971) Biochemical characteristics of insect microsomes and O-demethylation. Biochem Pharm 20:1569-1578

Harder HH, Riley SL, McCann SF, Irving SN (1996) DPXMP062: a novel broad-spectrum, environmentally soft, insect control 
compound. In: Proceedings of the Brighton conference, Brighton, UK

He F, Shiang S, Haili T, Xiao S, Chao Q, Shoumin J, Xiangdong L, Jiwang Z, Xingyin J (2019) Chlorantraniliprole against the black cutworm Agrotis ipsilon (Lepidoptera: Noctuidae): from biochemical/physiological to demographic responses. Sci Rep 9:10328. https://doi.org/10.1038/s41598-019-46915-0

Hull JJ, Fónagy A (2019) Molecular basis of pheromonogenesis regulation in moths. In: Picimbon J-F (ed) Olfactory concepts of insect control-alternative to insecticides. Springer, Cham, pp 151-202

Insecticide Resistance Action Committee, IRAC (2019) IRAC mode of action classification, Ver. 9.3, IRAC Mode of Action Working Group. http://www.MoA-Classification_v9.4_3March20\%20.pdf

Ishaaya I, Yablonski S, Horowitz AR (1995) Comparative toxicity of two ecdystroids, RH-2485 and RH-5992 on susceptible and pyrethroid resistant strains of the Egyption cotton leafworm, Spodoptera littoralis. Phytoparasit 23:139-145

Lahm GP, Selby TP, Freudenberger JH, Stevenson TM, Myers BJ, Seburyamo G, Smith BK, Flexner L, Clark CE, Cordova D (2005) Insecticidal anthranilic diamides: a new class of potent ryanodine receptor activators. Bioorg Med Chem Lett 15:4898-4906

Lahm GP, Cordova D, Barry JD (2009) New and selective ryanodine receptor activators for insect control. Bioorg Med Chem Lett $17: 4127-4133$

Lai T, Su J (2011) Assessment of resistance risk in Spodoptera exigua (Hübner) (Lepidoptera: Noctuidae) to chlorantraniliprole. Pest Manag Sci 67:1468-1472

Lanka SK, Ottea JA, Beuzelin JM, Stout MJ (2013) Effects of chlorantraniliprole and thiamethoxam rice seed treatments on egg numbers and first instar survival of Lissorhoptrus oryzophilus (Coleoptera: Curculionidae). J Econ Entomol 106:181-188

Liu DG, Trumble JT (2005) Interactions of plant resistance and insecticides on the development and survival of Bactericerca cockerelli [Sulc] (Homoptera: Psyllidae). Crop Prot 24:111-117

Liu H, Xiao P, Liu Y, He J, Qiu X, Jiao Y (2011) Resistance risk analysis and biochemical mechanism of Spodoptera litura to indoxacarb. Agrochemicals 50:197-200

Mahmoudvand M, Garjan AS, Abbasipour H (2011) Ovicidal effect of some insecticides on the diamondback moth, Plutella xylostella (Lepidoptera: Plutellidae). Chil J Agric Res 71(2):226-230

Marco MP, Fabriàs G, Lázaro G, Camps F (1996) Evidence for both humoral and neural regulation of sex pheromone biosynthesis in Spodoptera littoralis. Arch Insect Biochem Physiol 31:157-167

Moustafa MAM, Kákai A, Awad M, Fónagy A (2016) Sublethal effects of spinosad and emamectin benzoate on larval development and reproductive activities of the cabbage moth, Mamestra brassicae L. (Lepidoptera: Noctuidae). Crop Prot 90:197-204

Nesbitt BF, Beevor PS, Cole RA, Lester R, Poppi RG (1973) Sex pheromones of two noctuid moths. Nature 244:208-209

Parsaeyan E, Saber M, Bagheri M (2013) Toxicity of emamectin benzoate and cypermethrin on biological parameters of cotton bollworm, Helicoverpa armigera (Hübner) in laboratory conditions. Crop Prot 2:477-485

Percy JE, Weatherston J (1974) Gland structure and pheromone production in insects. In: Birch MC (ed) Pheromones. North Holland Publishing Company, Amsterdam, pp 11-34

Raina AK, Jaffe H, Klun JA, Ridgway RL, Hayes DK (1987) Characterization of a neurohormone that controls sex pheromone production in Heliothis zea. J Insect Physiol 33:809-814

SAS (2001) User guide: statistics (Release 8.02). SAS Institute, Cary, $\mathrm{NC}$
Sattelle DB, Cordova D, Cheek TR (2008) Insect ryanodine receptors: molecular targets for novel pest control chemicals. Invert Neurosci 8:107-119

Shen L-Z, Chen P-Z, Xu Z-H, Deng J-Y, Harris M-K, Wanna R, Wang F-M, Zhou G-X, Yao Z-L (2013) Effect of larvae treated with mixed biopesticide Bacillus thuringiensis-Abamectin on sex pheromone communication system in cotton bollworm, Helicoverpa armigera. Plos One 8:e68756

Sial AA, Brunner JF, Garczynski SF (2011) Biochemical characterization of chlorantraniliprole and spinetoram resistance in laboratory-selected obliquebanded leafroller, Choristoneura rosaceana (Harris) (Lepidoptera: Tortricidae). Pestic Biochem Physiol 99:274-279

Silvegren G, Löfstedt C, Rosén WQ (2005) Circadian mating activity and effect of pheromone pre-exposure on pheromone response rhythms in the moth Spodoptera littoralis. J Insect Physiol $51: 277-286$

Stark JD, Rangus TM (1994) Lethal and sublethal effects of the neem insecticide formulation',Margosan-O', on the pea aphid. Pestic Sci 41:155-160

Su J, Lai T, Li J (2012) Susceptibility of field populations of Spodoptera litura (Fabricius) (Lepidoptera: Noctuidae) in China to chlorantraniliprole and the activities of detoxification enzymes. Crop Prot 42:217-222

Tamaki Y, Yushima T (1974) Sex pheromone of the cotton leafworm, Spodoptera littoralis. J Insect Physiol 20:1005-1014

The Pherobase. http://www.pherobase.com/

Van Asperen K (1962) A study of housefly esterase by means of a sensitive colorimetric method. J Insect Physiol 8:401-416

Vojoudi S, Saber M, Gharekhani G, Esfandiari E (2017) Toxicity and sublethal effects of hexaflumuron and indoxacarb on the biological and biochemical parameters of Helicoverpa armigera (Hübner) (Lepidoptera: Noctuidae) in Iran. Crop Prot 91:100-107

Wang G, Huang X, Wei H, Fadamiro HY (2011) Sublethal effects of larval exposure to indoxacarb on reproductive activities of the diamondback moth, Plutella xylostella (L.) (Lepidoptera: Plutellidae). Pest Biochem Physiol 101:227-231

Wing KD, Schnee ME, Sacher M, Connair M (1998) A novel oxadiazine insecticide is bioactivated in lepidopteran larvae. Arch Insect Biochem Physiol 37:91-103

Wing KD, Sacher M, Kagaya Y, Tsurubuchi Y, Mulderig L, Connair M, Schnee M (2000) Bioactivation and mode of action of the oxadiazine indoxacarb in insects. Crop Prot 19:537-545

Yin X-H, Wu Q-J, Li X-F, Zhang Y-J, Xu B-Y (2008) Sublethal effects of spinosad on Plutella xylostella (Lepidoptera: Yponomeutidae). Crop Prot 27:1385-1391

Yu SJ (2004) Detoxification mechanisms in insects. In: Capinera JL (ed) Encyclopedia of entomology. Springer, Berlin, pp 1187-1201

Zhao X, Ikeda T, Salgado VL, Yeh JZ, Narahashi T (2005) Block of two types of sodium channels in cockroach neurons by indoxacarb insecticides. Neurotoxicology 26:455-465

Zhong H, Li F, Chen J, Zhang J, Li F (2017) Comparative transcriptome analysis reveals host-associated differentiation in Chilo suppressalis (Lepidoptera: crambidae). Sci Rep 7:13778

Publisher's Note Springer Nature remains neutral with regard to jurisdictional claims in published maps and institutional affiliations. 